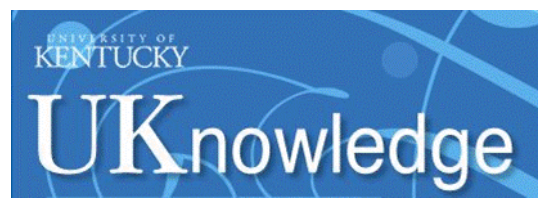

University of Kentucky

UKnowledge

$10-1-2013$

\title{
Conversion of lodide to Hypoiodous Acid and lodine in Aqueous Microdroplets Exposed to Ozone
}

\author{
Elizabeth A. Pillar \\ University of Kentucky, epillar86@gmail.com \\ Marcelo I. Guzman \\ University of Kentucky, marcelo.guzman@uky.edu \\ Jose M. Rodriguez \\ NASA Goddard Space Flight Center
}

Follow this and additional works at: https://uknowledge.uky.edu/chemistry_facpub

Part of the Analytical Chemistry Commons, Atmospheric Sciences Commons, Environmental

Chemistry Commons, Environmental Sciences Commons, Inorganic Chemistry Commons, and the

Physical Chemistry Commons

Right click to open a feedback form in a new tab to let us know how this document benefits you.

\section{Repository Citation}

Pillar, Elizabeth A.; Guzman, Marcelo I.; and Rodriguez, Jose M., "Conversion of lodide to Hypoiodous Acid and lodine in Aqueous Microdroplets Exposed to Ozone" (2013). Chemistry Faculty Publications. 17. https://uknowledge.uky.edu/chemistry_facpub/17

This Article is brought to you for free and open access by the Chemistry at UKnowledge. It has been accepted for inclusion in Chemistry Faculty Publications by an authorized administrator of UKnowledge. For more information, please contact UKnowledge@lsv.uky.edu. 
Conversion of lodide to Hypoiodous Acid and lodine in Aqueous Microdroplets Exposed to Ozone

\author{
Digital Object Identifier (DOI) \\ http://dx.doi.org/10.1021/es401700h \\ Notes/Citation Information \\ Published in Environmental Science \& Technology, v. 47, issue 19, p. 10971-10979. \\ (C) 2013 American Chemical Society
}

This is an open access article published under an ACS AuthorChoice License, which permits copying and redistribution of the article or any adaptations for non-commercial purposes.

This article is available at UKnowledge: https://uknowledge.uky.edu/chemistry_facpub/17 


\title{
Conversion of lodide to Hypoiodous Acid and lodine in Aqueous Microdroplets Exposed to Ozone
}

\author{
Elizabeth A. Pillar, ${ }^{\dagger}$ Marcelo I. Guzman, ${ }^{* \dagger}$ and Jose M. Rodriguez \\ ${ }^{\dagger}$ University of Kentucky, Department of Chemistry, Lexington, Kentucky 40506, United States \\ ${ }^{\ddagger}$ NASA Goddard Space Flight Center, Greenbelt, Maryland 20771, United States
}

Supporting Information

ABSTRACT: Halides are incorporated into aerosol sea spray, where they start the catalytic destruction of ozone $\left(\mathrm{O}_{3}\right)$ over the oceans and affect the global troposphere. Two intriguing environmental problems undergoing continuous research are (1) to understand how reactive gas phase molecular halogens are directly produced from inorganic halides exposed to $\mathrm{O}_{3}$ and (2) to constrain the environmental factors that control this interfacial process. This paper presents a laboratory study of the reaction of $\mathrm{O}_{3}$ at variable iodide $\left(\mathrm{I}^{-}\right)$concentration $(0.010-100 \mu \mathrm{M})$ for solutions aerosolized at $25{ }^{\circ} \mathrm{C}$, which reveal remarkable differences in the reaction intermediates and products expected in sea spray for low tropospheric $\left[\mathrm{O}_{3}\right]$. The ultrafast oxidation of $\mathrm{I}^{-}$by $\mathrm{O}_{3}$ at the air-water interface of microdroplets is evidenced by the appearance of hypoiodous acid ( $\mathrm{HIO}$ ), iodite $\left(\mathrm{IO}_{2}^{-}\right)$, iodate $\left(\mathrm{IO}_{3}^{-}\right)$, triiodide $\left(\mathrm{I}_{3}^{-}\right)$, and molecular iodine $\left(\mathrm{I}_{2}\right)$.

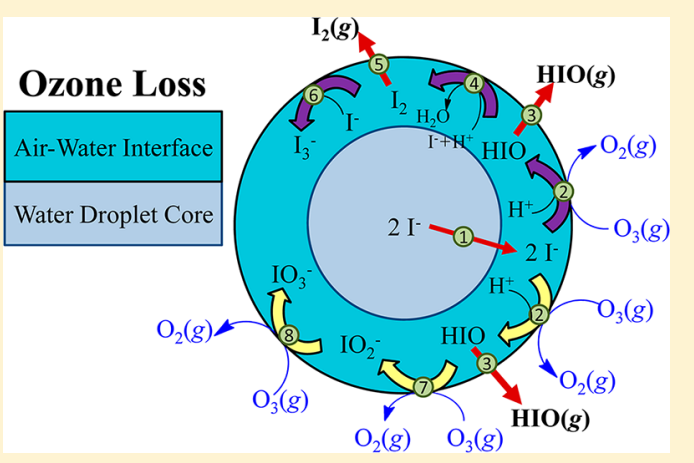

Mass spectrometry measurements reveal an enhancement (up to 28\%) in the dissolution of gaseous $\mathrm{O}_{3}$ at the gas-liquid interface when increasing the concentration of $\mathrm{NaI}$ or $\mathrm{NaBr}$ from 0.010 to $100 \mu \mathrm{M}$. The production of iodine species such as $\mathrm{HIO}$ and $\mathrm{I}_{2}$ from $\mathrm{NaI}$ aerosolized solutions exposed to 50 ppbv $\mathrm{O}_{3}$ can occur at the air-water interface of sea spray, followed by their transfer to the gas-phase, where they contribute to the loss of tropospheric ozone.

\section{INTRODUCTION}

Increasing levels of greenhouse gases in the atmosphere over the past 160 years have led to a significant climate perturbation in the present time scale. ${ }^{1}$ Ozone, $\mathrm{O}_{3}(\mathrm{~g})$, near the tropopause is an important greenhouse gas. Thus, a better understanding of the anthropogenic effects on climate requires the full characterization of the pathways of production and destruction of tropospheric $\mathrm{O}_{3}(\mathrm{~g})$. Ozone molecules also play a key role in tropospheric chemistry, absorb infrared radiation, and have adverse effects in air quality and public health. The major source of ozone in the lower atmosphere is the oxidation of organic compounds and carbon monoxide in the presence of nitrogen oxides occurring over the continents, followed by a minor contribution from stratospheric influx. ${ }^{2,3}$ Ozone is transported from continental regions to the marine boundary layer $(\mathrm{MBL})$, where major ozone loss occurs, primarily due to photolysis in the presence of water. However, the ozone loss calculated with all known losses, excluding halogens, accounts for only about $50 \%$ of the observed loss. ${ }^{4}$

Similarly to the stratospheric destruction of ozone by chlorine and bromine, halogen species emitted from surface waters, can contribute to the global decrease of ozone levels. ${ }^{4}$ The destruction of tropospheric $\mathrm{O}_{3}(\mathrm{~g})^{5,6}$ occurs at air-water and air-ice interfaces, mediated by heterogeneous reactions ${ }^{7-10}$ catalyzed by organic species. ${ }^{11-13}$ The activation of halogens, such as $\mathrm{Br}_{2}$ and $\mathrm{I}_{2}$, to participate in the photochemical depletion of tropospheric ozone remains poorly understood. ${ }^{14}$ It is well- known that marine macroalgae in coastal regions produce $I_{2}$, rather than iodine-containing organic compounds, which is transferred to the atmosphere and photoactivated to release iodine atoms. ${ }^{15,16}$ However, measurements over the open ocean cannot be explained by this mechanism of $\mathrm{O}_{3}$ loss. ${ }^{17}$ Perhaps, a major contribution to the loss of tropospheric ozone over the open ocean originates from inert halide ions (e.g., $\mathrm{Br}^{-}$ and $\left.\mathrm{I}^{-}\right)^{18,19}$ or oxyanions (e.g., $\left.\mathrm{IO}_{3}^{-}\right),{ }^{20}$ which are somehow converted into molecular halogens (e.g., $\mathrm{Br}_{2}$ and $\mathrm{I}_{2}$ ), and reactive halogen species, $\mathrm{RHS}\left(\right.$ e.g., $\mathrm{Br}^{\bullet}, \mathrm{BrO}^{\bullet}$, and $\mathrm{IO}^{\bullet}$ ). RHS deplete the level of $\mathrm{O}_{3}(\mathrm{~g})$ ( $\left.\sim 50 \mathrm{ppbv}\right)$ during early spring in the Artic troposphere. ${ }^{5,21-23}$ The production of $\mathrm{I}_{2}(\mathrm{~g})$ and $\mathrm{HOI}(\mathrm{g})$ from submicromolar levels of aqueous $\mathrm{I}^{-}$reacting with $\mathrm{O}_{3}(\mathrm{~g})$ in the top micrometer surface layer of the ocean $\left(\mathrm{pH}_{\text {ocean }} \approx 8\right)^{24}$ functions as a source of $\mathrm{IO}^{\bullet}$ radicals independent of the bulk $\mathrm{pH}^{23}$

The process of sea spray formation generates negatively charged droplets that contain dissolved halides salts ${ }^{25}$ and establishes a negative current into the atmospheric boundary layer. $^{26,27}$ We have previously shown how the fractionation of halides species occurring at the air-water interface ${ }^{28,29}$ during aerosol formation depends mainly on the concentration of

Received: April 19, 2013

Revised: August 26, 2013

Accepted: August 29, 2013

Published: August 29, 2013 
species present in surface waters that is strongly biased by the size of the ions. ${ }^{18}$ However, the remaining question to be answered is: How do those aerosolized inert halide salts are later oxidized to become RHS in the air ${ }^{14,30}$ Thus, it is crucial to identify the mechanisms of production of halogen oxides in the tropical MBL.,31-34 Electrospray ionization mass spectrometer (ESI-MS) was recently used at high temperature (350 ${ }^{\circ} \mathrm{C}$ ) to propose that interfacial reactivity patterns exist in microdroplets. ${ }^{35,36}$ However, experiments at lower temperature are needed together with a detailed analysis of the direct reaction products and intermediates for the reaction of iodide at variable ozone concentration to model the loss of ozone. In this article, we investigate a widespread effect of halides reactions with ozone to produce $I_{2}$ and reactive species at the air-water interface at $25{ }^{\circ} \mathrm{C}$ to simulate the nonphotochemical processes occurring in the MBL. We report the enhanced dissolution of $\mathrm{O}_{3}$ in aerosolized microdroplets with increasing sodium halide $\left(\mathrm{X}^{-}=\mathrm{Br}^{-}, \mathrm{I}^{-}\right)$concentration $(10 \mathrm{nM}-100 \mu \mathrm{M})$. In addition, we study the cycle of ozone destruction on microdroplets by freshly produced iodine species, such as $\mathrm{HIO}$, $\mathrm{HIO}_{2}$, and $\mathrm{HIO}_{3}$, the effect of polysorbate 20 surfactant to enhance or suppress the production of iodine species, and detect for the first time the reaction intermediate $\mathrm{HI}_{2} \mathrm{O}^{-}$for the production of $\mathrm{I}_{2}$.

\section{EXPERIMENTAL SECTION}

Solutions of sodium salts ( $\mathrm{NaI}$ and $\mathrm{NaBr}$ ) were prepared daily in ultrapure water $(18.2 \mathrm{M} \Omega-\mathrm{cm})$, methanol, or acetonitrile, and infused into a calibrated ESI-MS (Thermo Scientific, MSQ Plus). Polysorbate 20 was used as a nonionic surfactant. Figures report the normalized ion count for experiments at $\mathrm{pH}$ 6.2, unless otherwise indicated, which agree with the observations at $\mathrm{pH} 6.8$ and 8.1. The $\mathrm{pH}$ of solutions was adjusted with $0.01 \mathrm{M}$ $\mathrm{NaOH}$ and measured with a calibrated $\mathrm{pH}$-meter (Mettler Toledo). All species are in the aqueous state, that is, $\mathrm{I}^{-}(\mathrm{aq}) \equiv$ $\mathrm{I}^{-}$, unless indicated otherwise.

In our ESI system (Scheme 1), described in more detail before $^{18}$ and in the Supporting Information, a solution of electrolytes undergoes pneumatically assisted aerosolization to be converted into fine micrometer size droplets at atmosphericpressure. The microdroplets encounter a flow of $\mathrm{O}_{3}(\mathrm{~g})(0.2 \mathrm{~L}$

Scheme 1. Reactor Diagram

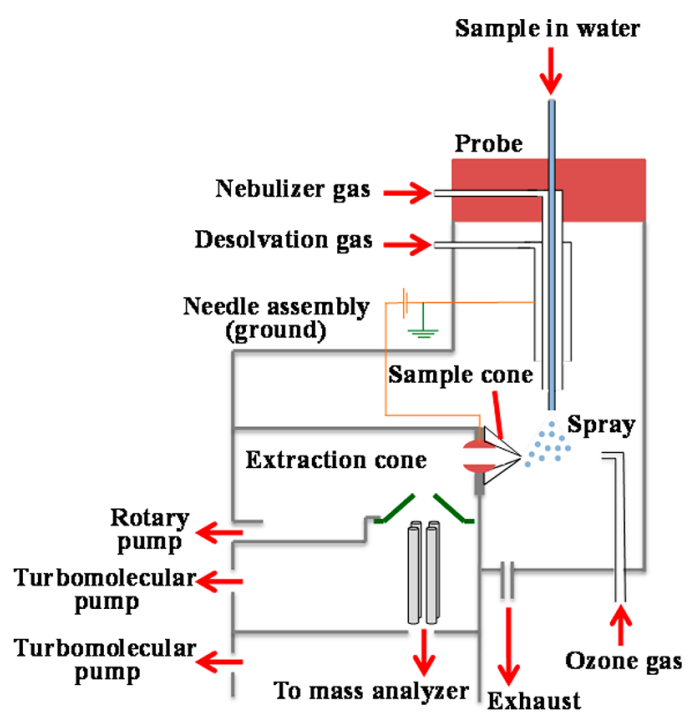

$\min ^{-1}$ ) produced in a spark discharge ozone generator (Ozone Solutions) fed with $\mathrm{O}_{2}(\mathrm{~g})$. The ultrahigh purity gases used were from Scott-Gross. UV absorption spectrophotometry allows the quantification of $\mathrm{O}_{3}(\mathrm{~g})^{37}$ diluted in $\mathrm{N}_{2}(\mathrm{~g})$ in a $10-\mathrm{cm}$ path length cuvette (Supporting Information), which is transported to a stainless steel tube, positioned $32 \mathrm{~mm}$ far from the entrance cone and $12 \mathrm{~mm}$ from the needle tip carrying the solution. Furthermore, a final 61-times dilution with the $\mathrm{N}_{2}(g)$ nebulizing gas $\left(12.0 \mathrm{~L} \mathrm{~min}^{-1}\right)$ occurs in the chamber. Therefore, the experiments yield fundamental mechanistic information covering the low $\left[\mathrm{O}_{3}(g)\right]$ found in the troposphere.

The encounter of $\mathrm{O}_{3}(\mathrm{~g})$ with the microdroplets containing $\mathrm{I}^{-}$ produces oxidized species. The overall time from the formation of droplets, transport through the $\mathrm{O}_{3}(\mathrm{~g})$ plume, and ion detection is $<1 \mathrm{~ms}$. However, the contact time between $\mathrm{O}_{3}(\mathrm{~g})$ and the plume of microdroplets is $\tau \approx 1 \mu$ s (Supporting Information). In summary, the experimental conditions were: Drying gas temperature, $25{ }^{\circ} \mathrm{C}$; nebulizer voltage, $-2.5 \mathrm{kV}$; cone voltage, $-70 \mathrm{~V}$; and nebulizer pressure, $70 \mathrm{psi}$. The solvent background was subtracted from the mass spectrum of the sample acquired at fixed time intervals (e.g., time $\geq 1 \mathrm{~min}$ ). More details of the experimental methods are available as Supporting Information.

\section{RESULTS AND DISCUSSION}

Reactions of Ozone with lodide at the Air-Water Interface. Figure 1 shows electrospray mass spectra of aerosolized $\mathrm{NaI}$ aqueous solutions exposed to a flow of $0.2 \mathrm{~L}$ $\min ^{-1}$ (A) $\mathrm{N}_{2}$ (g), (B) $50 \mathrm{ppbv}$, (C) $130 \mathrm{ppbv}$, (D) $492 \mathrm{ppbv}$, and $(\mathrm{E}) 1.393 \mathrm{ppmv}$ ppmv $_{3}(\mathrm{~g})$ at $\mathrm{pH}=6.2$. In the absence of ozone (Figure $1 \mathrm{~A})$, only $\mathrm{I}^{-}(\mathrm{m} / z=127)$ is detected. Upon addition of $50 \mathrm{ppbv} \mathrm{O}_{3}(\mathrm{~g})$, significant changes are observed (Figure 1B), the ion count of $\mathrm{I}^{-}$decreases and new peaks appear: $\mathrm{IO}^{-}(m / z=143$, the conjugate base of $\mathrm{HIO})$ and its hydrate $\mathrm{H}_{2} \mathrm{O} \cdot \mathrm{IO}^{-}(m / z=161)$, a trace of $\mathrm{IO}_{2}^{-}(m / z=159),{ }^{38}$ $\mathrm{I}_{2}$ (detected as $\mathrm{I}_{2}^{-}$at $m / z=254$ ) becomes the dominant peak, ${ }^{39}$ $\mathrm{HI}_{2} \mathrm{O}^{-}(m / z=271)$ the short-lived reaction intermediate for the production of $\mathrm{I}_{2}$, a practically imperceptible trace of $\mathrm{NaI}_{2}{ }^{-}$ $(m / z=277)$ cluster, ${ }^{40}$ and $\mathrm{I}_{3}{ }^{-}(\mathrm{m} / z=381) .{ }^{41}$ The same products are observed for $130 \mathrm{ppbv}_{3}(\mathrm{~g})$ (Figure 1C). A farther increase to $492 \mathrm{ppbv} \mathrm{O}_{3}(\mathrm{~g})$ clearly shows (1) the appearance of additional peaks (Figure 1D) for aqueous $\mathrm{O}_{3}$ (detected as $\mathrm{O}_{3}{ }^{-}$at $\left.m / z=48\right), \mathrm{IO}_{3}^{-}(m / z=175)$, (2) an enhancement in the ion count of $\mathrm{IO}^{-}, \mathrm{IO}_{2}^{-}, \mathrm{H}_{2} \mathrm{O} \cdot \mathrm{IO}^{-},(3)$ a decrease of $\mathrm{I}^{-}, \mathrm{I}_{2}, \mathrm{I}_{3}^{-}$, and (4) the complete loss of $\mathrm{HI}_{2} \mathrm{O}^{-}$. An increase in the production of $\mathrm{IO}_{3}{ }^{-}$is detected at $1.393 \mathrm{ppmv}$ $\mathrm{O}_{3}(\mathrm{~g})$ (Figure $1 \mathrm{E}$ ).

The fact that we detect neutral species, such as $\mathrm{O}_{3}$ and $\mathrm{I}_{2}$, imply that a mechanism of charge transfer is operative. Because $\mathrm{m} / z=48$ is not detected in a control without water, we propose that $(1) \mathrm{O}_{3}(\mathrm{~g})$ dissolves in the droplet containing ions in the early stage of aerosolization, (2) droplet evaporation occurs accompanied by fission in smaller droplets, and (3) finally the production of $\mathrm{O}_{3}{ }^{--}$takes place from the latest progeny droplets that are the direct precursor to form the ions that reach the detector. Solvent and gas molecules are pumped away in the intermediate vacuum stage between the ESI probe and analyzer. Charge transfer to $\mathrm{O}_{3}(\mathrm{aq})$ occurs in the last step of ion formation, and a posteriori of the observed reactions. Therefore, the detected $\mathrm{O}_{3}{ }^{\bullet-}$ does not play a role as a reagent in our system, and the reactions observed are from the direct interaction of $\mathrm{I}^{-}$with molecular $\mathrm{O}_{3}$. Otherwise, different chemistry would have resulted from $\mathrm{O}_{3}{ }^{--}$that quickly generates 


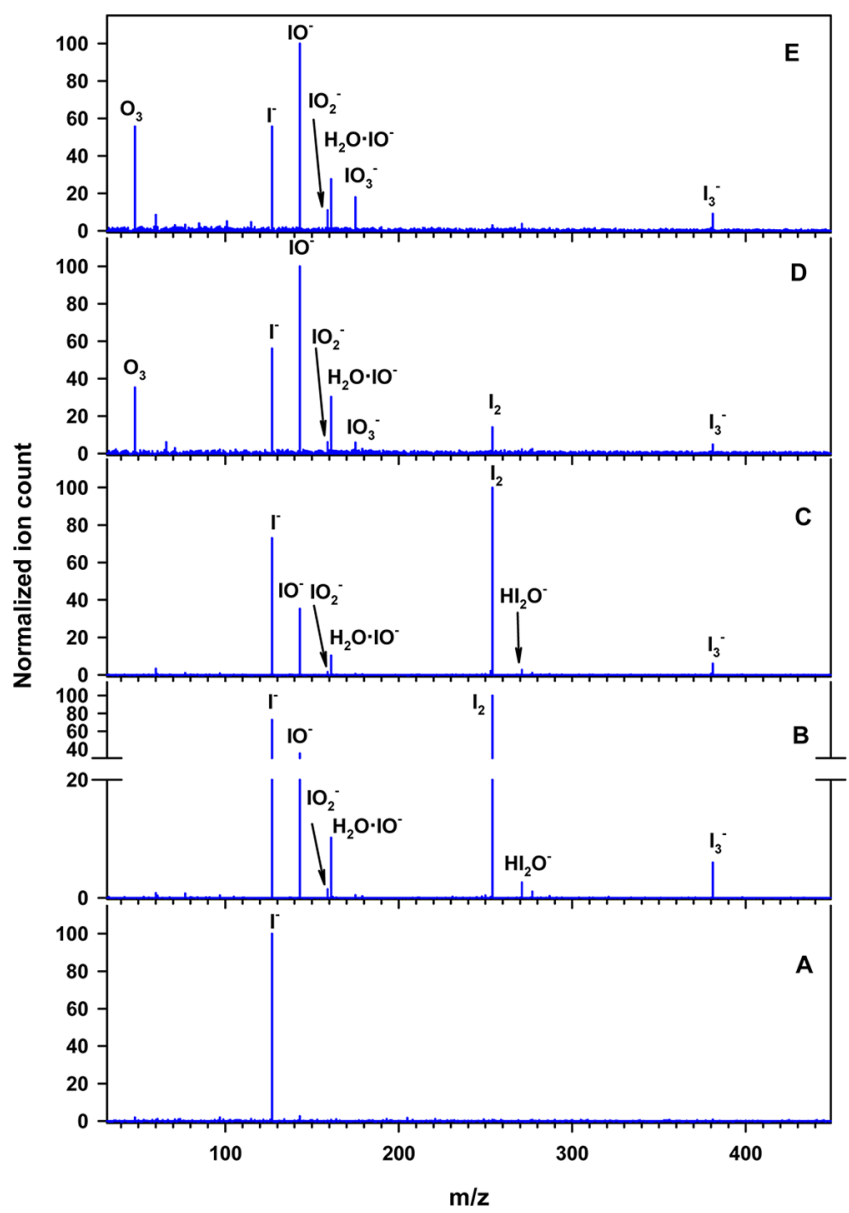

Figure 1. Spectra of ESI-MS of $50 \mu \mathrm{M}$ solution of $\mathrm{NaI}$ at $\mathrm{pH}=6.2$ exposed to a $0.200 \mathrm{~L} \mathrm{~min}^{-1}$ flow (A) $1 \mathrm{~atm} \mathrm{~N}_{2}$ (g), (B) $50 \mathrm{ppbv}$, (C) $130 \mathrm{ppbv}$, (D) $492 \mathrm{ppbv}$, and (E) $1.393 \mathrm{ppmv} \mathrm{O}_{3}(\mathrm{~g})$. Ion count values are normalized relative to the most intense peak in the mass spectrum.

$\mathrm{HO}^{\bullet}$ in water, which could neither predict the abundance of $\mathrm{I}_{3}{ }^{-}$ observed nor the formation of $\mathrm{IO}_{3}{ }^{-42}$

Figure 2 shows how the ion count of $\mathrm{I}^{-}, \mathrm{I}_{2}, \mathrm{IO}^{-}, \mathrm{H}_{2} \mathrm{O} \cdot \mathrm{IO}^{-}$, $\mathrm{I}_{3}^{-}, \mathrm{IO}_{2}^{-}$, and $\mathrm{IO}_{3}^{-}$exponentially rise to a maximum for increasing initial $\left[\mathrm{I}^{-}\right]$at constant $\left[\mathrm{O}_{3}(\mathrm{~g})\right]$. Note that although $\mathrm{I}_{2}$ is the largest peak at $130 \mathrm{ppbv} \mathrm{O}_{3}(\mathrm{~g}$ ) (Figure 2A), this observation cannot be interpreted as a higher $\left[\mathrm{I}_{2}\right]$ than $\left[\mathrm{I}^{-}\right]_{0}$. Simple stoichiometry shows that for a $\sim 20 \%$ loss of $\left[\mathrm{I}^{-}\right]_{0}=100$ $\mu \mathrm{M}$, a theoretical maximum of $10 \mu \mathrm{M} \mathrm{I}_{2}$ could be produced. Indeed, the production of other iodine species establishes a lower yield for the production of $\mathrm{I}_{2}$. We interpret the large ion count of $\mathrm{I}_{2}$ as being correlated to the high tendency of this species to partition into the gas phase and form ions. ${ }^{43}$ Furthermore, the chemical species are enriched or depleted at the air-water interface depending not only on their relative concentrations but also on size. ${ }^{18}$ Under low $\mathrm{O}_{3}(\mathrm{~g})$ conditions, $\mathrm{I}_{2}$ reacts farther to generate $\mathrm{I}_{3}{ }^{-}$(reaction 6). An increase to 492 ppbv $\mathrm{O}_{3}(\mathrm{~g})$ (Figure $2 \mathrm{~B}$ ) produces a dominant $\mathrm{IO}^{-}$peak and its hydrate, capable of evolving to the gas phase as HIO given its high $\mathrm{p} K_{\mathrm{a}}$. HIO and its hydrate are also unstable and undergo farther processing through two channels for the production of (1) $\mathrm{I}_{3}^{-}$and (2) $\mathrm{IO}_{3}{ }^{-}$. The mechanism is shifted to produce the $\mathrm{IO}_{2}^{-}$intermediate conducting to $\mathrm{IO}_{3}^{-}$final product at 1.393 ppmv $\mathrm{O}_{3}\left(\mathrm{~g}\right.$ ) (Figure 2C). While at 50 and $130 \mathrm{ppbv}, \mathrm{I}_{3}{ }^{-}$is a final reaction product, the mechanism must shift somehow at

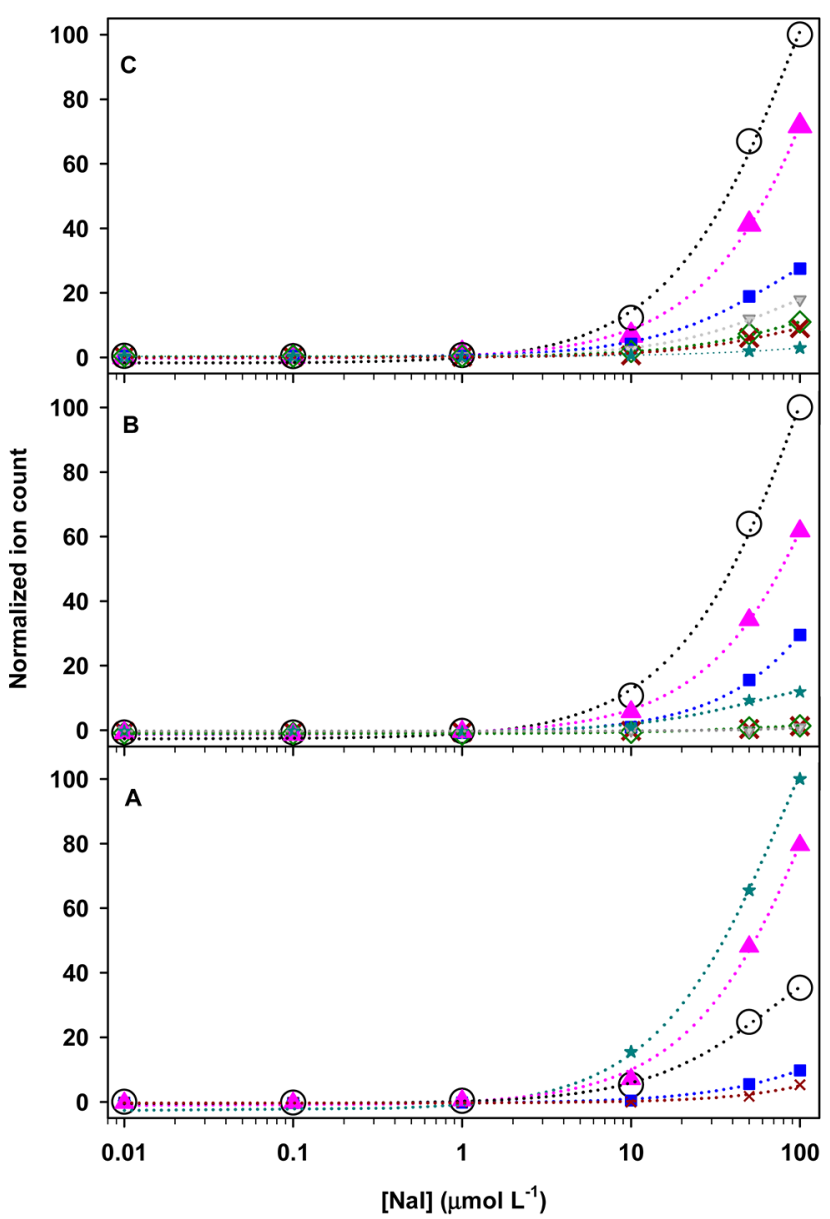

Figure 2. Semilogarithmic plots of normalized ion count for (pink $\mathbf{A}$ ) $\mathrm{I}^{-}$, (teal star) $\mathrm{I}_{2}$, (open circle) $\mathrm{IO}^{-}$, (blue square) $\mathrm{H}_{2} \mathrm{O} \cdot \mathrm{IO}^{-},($red $\times$) $\mathrm{I}_{3}{ }^{-}$, (green open diamond) $\mathrm{IO}_{2}{ }^{-}$, and (gray inverted triangle) $\mathrm{IO}_{3}{ }^{-}$in the ESI mass spectra as a function of increasing $[\mathrm{NaI}]$ at $\mathrm{pH}=6.2$. Aerosolized solutions are exposed to (A) $130 \mathrm{ppbv}$, (B) $492 \mathrm{ppbv}$, and (C) 1.393 ppmv $\mathrm{O}_{3}(\mathrm{~g})$.

$1.393 \mathrm{ppm}$ because this species appears to be less abundant than $\mathrm{IO}_{3}^{-}$.

The results in Figures 1 and 2 are summarized in Scheme 2. The experiments at variable $\mathrm{O}_{3}(\mathrm{~g})$ concentration may proceed

Scheme 2. Reactions of Iodide in Aqueous Microdroplets Exposed to $\mathrm{O}_{3}(\mathrm{~g})$

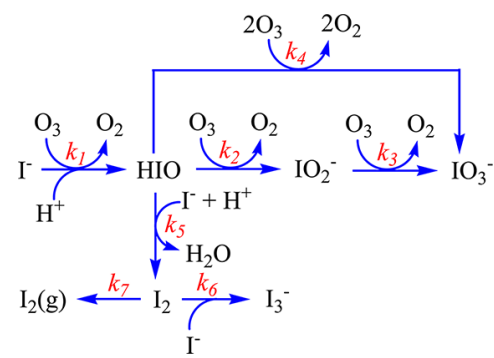

at the interface by the exothermic reaction: $\mathrm{I}^{-}+\mathrm{O}_{3} \rightarrow \mathrm{IOOO}^{-}$ $\rightarrow \mathrm{IO}^{-}+\mathrm{O}_{2}{ }^{23}$ The progression of the data in Figures 1 and 2, and the dependence with ozone partial pressure, $P_{\mathrm{O}_{3}}$, indicate that the detection of the unstable intermediate $\mathrm{IOOO}^{-}$seems unlikely in these experiments. However, if the intermediate is present even at very low concentration, its mass spectrum 
Table 1. Chemical Reactions and Kinetic and Equilibrium Constants in Water at Room Temperature ${ }^{a}$

\begin{tabular}{cl} 
reaction number & \multicolumn{1}{c}{ reaction } \\
R1 & $\mathrm{I}^{-}+\mathrm{O}_{3}+\mathrm{H}^{+} \rightarrow \mathrm{HIO}+\mathrm{O}_{2}$ \\
$\mathrm{R} 2$ & $\mathrm{HIO}+\mathrm{O}_{3} \rightarrow \mathrm{IO}_{2}^{-}+\mathrm{O}_{2}+\mathrm{H}^{+}$ \\
$\mathrm{R} 3$ & $\mathrm{IO}_{2}^{-}+\mathrm{O}_{3} \rightarrow \mathrm{IO}_{3}^{-}+\mathrm{O}_{2}$ \\
R4 & $\mathrm{HIO}+2 \mathrm{O}_{3} \rightarrow \mathrm{IO}_{3}^{-}+2 \mathrm{O}_{2}+\mathrm{H}^{+}$ \\
R5 & $\mathrm{HIO}+\mathrm{I}^{-}+\mathrm{H}^{+} \rightarrow \mathrm{I}_{2}+\mathrm{H}_{2} \mathrm{O}$ \\
$\mathrm{R} 6$ & $\mathrm{I}_{2}+\mathrm{I}^{-} \rightleftharpoons \mathrm{I}_{3}^{-}$ \\
R7 & $\mathrm{I}_{2} \rightleftharpoons \mathrm{I}_{2}(\mathrm{~g})$ \\
R8 & $\mathrm{HIO} \rightleftharpoons \mathrm{HIO}(\mathrm{g})$
\end{tabular}

$\begin{array}{ll}\text { rate or equilibrium constant } & \text { ref } \\ k_{1}=2.4 \times 10^{9} \mathrm{M}^{-1} \mathrm{~s}^{-1} & 46 \\ b & \\ b & \\ k_{4}=3.6 \times 10^{4} \mathrm{M}^{-1} \mathrm{~s}^{-1} & 38 \\ k_{5}=4.4 \times 10^{12} \mathrm{M}^{-2} \mathrm{~s}^{-1} & 39 \\ K_{6}=721 \mathrm{M}^{-1}, k_{6}=6.2 \times 10^{9} \mathrm{M}^{-1} \mathrm{~s}^{-1}, k_{-6}=8.5 \times 10^{6} \mathrm{~s}^{-1} & 41 \\ K_{7}=0.33 \mathrm{~atm} \mathrm{M} \mathrm{M}^{-1} & 43 \\ K_{8}=5.34 \times 10^{-3} \mathrm{~atm} \mathrm{M} \mathrm{M}^{-1} & 45\end{array}$

${ }^{a}$ All species are aqueous or liquids unless otherwise indicated. ${ }^{b}$ Unkown.

would overlap the major isomeric $\mathrm{IO}_{3}{ }^{-}$product at $m / z=175$, making it undistinguishable for this technique. For relevant $\mathrm{pH}$ values in sea spray aerosols and surface ocean waters $(\mathrm{pH}+2<$ $\left.\mathrm{pK}_{\mathrm{a}, \mathrm{HIO}}=10.4\right),{ }^{44}$ the fully undissociated hypoiodous acid, $\mathrm{HIO}$, is practically the only species in the acid-base equilibrium, and therefore the precursor of $\mathrm{I}_{3}^{-}$and $\mathrm{IO}_{3}{ }^{-}$. Thus, the reaction rate equations for the consumption of the conjugate base $\mathrm{IO}^{-}$with $\mathrm{O}_{3}(\mathrm{~g})$ and $\mathrm{I}^{-}$can be neglected.

In more detail, at low ozone concentrations (Figures $1 \mathrm{~B}, \mathrm{C}$ and $2 \mathrm{~A}$ ), the iodide solution is converted to $\mathrm{I}_{3}^{-}$through reactions 1,5 , and 6 (see Table 1 ) during aerosolization. From the viewpoint of an environmentally relevant process, reaction 1 plays a major role to feed the transfer of RHS to the gasphase, as recently demonstrated by Carpenter et al., who reported a large emission ratio $\mathrm{HIO}(\mathrm{g}) / \mathrm{I}_{2}(\mathrm{~g}) \approx 10$, using a model with a reacto-diffusive length of $\sim 1 \mu \mathrm{m}$ undergoing processing during hours, ${ }^{24}$ which should not be compared to the experimental $\delta$ and $\tau$ used herein. Alternatively, the fate of iodide can be the production of iodate $\left(\mathrm{IO}_{3}{ }^{-}\right)$(Figure 1E) at higher ozone levels. For high $P_{\mathrm{O}_{3}}$, $\mathrm{HIO}$ undergoes oxidation to $\mathrm{IO}_{3}^{-}$in a sequential process described by reactions 2 and 3 (Table 1). Because HIO is produced at the interface, its tendency to escape to the gas-phase should be higher than predicted ${ }^{45}$ for typical bulk processes. The $\mathrm{IO}_{3}{ }^{-}$production pathway, with unknown reaction rate constants, is summarized by overall reaction 4 (Scheme 2 ). Although the rate constant for the oxidation of $\mathrm{IO}_{2}^{-}$, reaction 3 , is unknown, it should proceed faster than the preceding reaction 2 , and therefore is not the rate limiting step.

Ozone Concentration Effect. Figure 3A shows the linear dependence for the branching ratio $\left[\mathrm{IO}_{3}^{-}\right] /\left[\mathrm{I}_{3}^{-}\right]$when $100 \mu \mathrm{M}$ $\mathrm{I}^{-}$reacts with increasing $\left[\mathrm{O}_{3}(\mathrm{~g})\right]$, in agreement with the mechanism in Scheme 2. The branching ratio is directly derived from the data in panels $\mathrm{C}$ and $\mathrm{D}$ of Figure 3 . The loss of $\left[\mathrm{I}^{-}\right]$in microdroplets appears to reach steady state conditions for $\left[\mathrm{O}_{3}(\mathrm{~g})\right], 1.64 \mathrm{ppmv}$ (Figure 3B). The reactions of $\mathrm{I}^{-}$and its follow-up products occur so quickly that other reactions of $\mathrm{I}^{-}$, such as with $\mathrm{HO}^{\bullet}$ radicals, can be disregarded. ${ }^{42}$

Figure 3 also shows that above 3.28 and $1.20 \mathrm{ppmv} \mathrm{O}_{3}(\mathrm{~g})$ the respective $\mathrm{HIO}$ and $\mathrm{I}_{2}$ species reach a stationary state production in our continuous flow reactor. Remarkably, the high abundance of the intermediate $\mathrm{HIO}$ for all $\left[\mathrm{O}_{3}(\mathrm{~g})\right]$ range above $130 \mathrm{ppbv}$, which has the largest ion count relative to the other species, reaches a maximum at $1.47 \mathrm{ppmv}$, while it is further oxidized in the microdroplets or transferred to the gasphase. However, the higher counts for the peak at $\mathrm{m} / z=254$ (Figure 3E) than for $\mathrm{m} / z=143$ (panel F) below $130 \mathrm{ppbv}$ $\mathrm{O}_{3}(\mathrm{~g})$ suggests that $\mathrm{I}_{2}$ should be considered in models that describe the chemistry over surface ocean waters. At low ozone concentration, $I_{2}$ reaches a maximum, when the production of

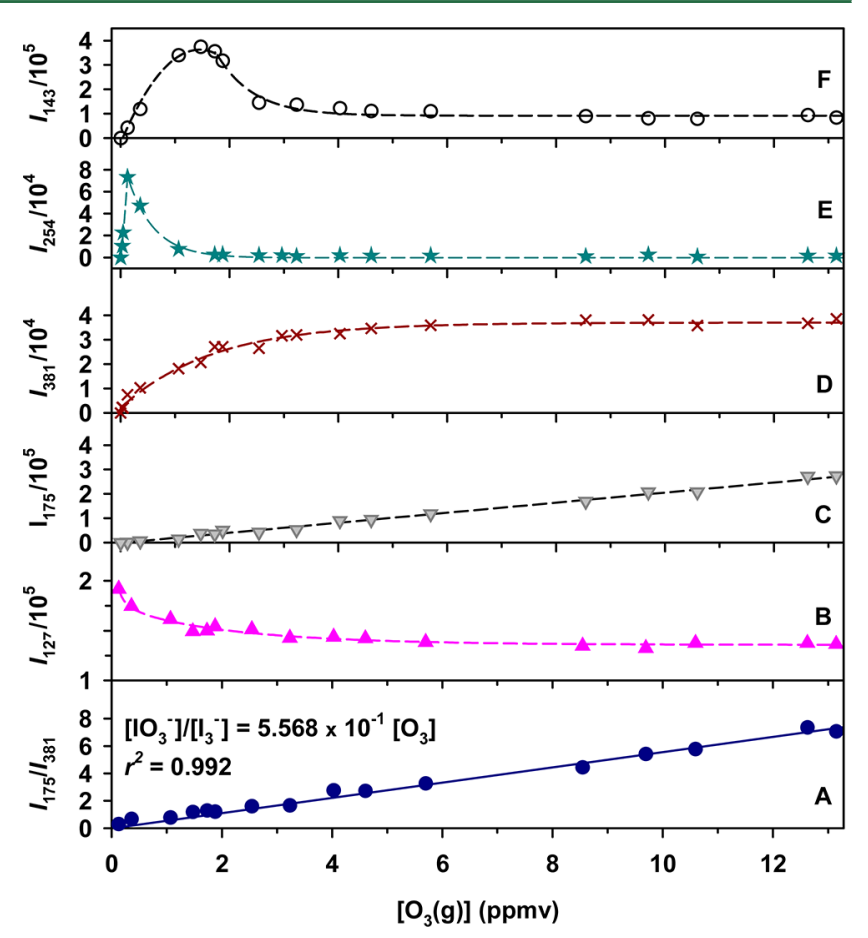

Figure 3. (A) Ratio of production of ions $\mathrm{IO}_{3}{ }^{-}$and $\mathrm{I}_{3}{ }^{-}, \mathrm{I}_{175} / \mathrm{I}_{381}$, as a function of $\left[\mathrm{O}_{3}(\mathrm{~g})\right]$ for $\left[\mathrm{I}^{-}\right]_{0}=100 \mu \mathrm{M}$ at $\mathrm{pH}=6.2$. The data is fitted with a linear regression curve through the origin. Ion count, $I_{m / z}$ for the loss of (B) $\mathrm{I}^{-}$, and production of (C) $\mathrm{IO}_{3}^{-}$, (D) $\mathrm{I}_{3}^{-},(\mathrm{E}) \mathrm{I}_{2}$, and (F) $\mathrm{IO}^{-}$with increasing $\left[\mathrm{O}_{3}(\mathrm{~g})\right]$.

$\mathrm{HIO}$ is growing from its minimum, but decays exponentially at high $\left[\mathrm{O}_{3}(\mathrm{~g})\right]$. The production of $\mathrm{IO}_{3}^{-}$and $\mathrm{I}_{3}^{-}$(Table 1 , reactions 4 and 6) in thin slabs occurs simultaneously with the fast replenishment of $\mathrm{I}^{-}$loss from a contiguous internal layer, resulting in product yields that exceed unity at the interface even at room temperature. This surprising result agrees with the observations made by Enami and co-workers at very high temperature $\left(T \geq 340{ }^{\circ} \mathrm{C}\right)$ in a different instrumental setup. ${ }^{35,36}$ Thus, the experiments support the proposal that classical bulk solution models cannot be applied to explain the kinetics and mechanisms of reactions at the interface of microdroplets and sea spray aerosols. ${ }^{22}$ Therefore, these observations need to be taken into account in future models that describe ozone loss mediated by iodine species emitted from sea spray aerosol.

Diffusion of $\mathrm{I}^{-}$through an ultrathin interface (Supporting Information) occurs from the core of the droplet while reactions occur in a contact time $\tau \approx 1 \mu \mathrm{s}$, on a nanoscopic interface of thickness $\delta \approx 1 \mathrm{~nm}$ (Supporting Information). ${ }^{48}$ The value of $\delta$ used agrees with related ESI-MS studies and 
second harmonic generation measurements. ${ }^{29,48,49}$ A rigorous mathematical solution to the system requires working with differential equations describing the reaction kinetics, including diffusion through a sharp boundary. ${ }^{50}$ However, classical methods for fixed volume batch reactors may not be valid to model present experiments with microdroplets, ${ }^{51}$ where the transport of species by diffusion is neither occurring over lengths that are much larger than the mean free paths, nor homogeneous. $^{18}$

The fact that Figure 3B levels off indicates the lack of diffusion controlled limitations. Because $\mathrm{I}^{-}$diffuses in a few nanoseconds through the $\delta=1 \mathrm{~nm}$ layer, a stationary state $\left(\mathrm{d}\left[\mathrm{I}^{-}\right] / \mathrm{d} t=0\right)$ is quickly established during our measurements. Assuming that the final products $\mathrm{IO}_{3}{ }^{-}$and $\mathrm{I}_{3}{ }^{-}$are generated at faster rates than the previous intermediates $\mathrm{IO}_{2}{ }^{-}$and $\mathrm{I}_{2}, k_{2} \ll k_{3}$ and $k_{5} \ll k_{6}$, Scheme 2 predicts the linearity observed in Figure $3 \mathrm{~A}$ between the ion count for both final products and $\left[\mathrm{O}_{3}\right]$. Remarkably, because of the contribution of intradroplet diffusion to the detected interfacial $\left[\mathrm{I}^{-}\right]$, the outer layer of the droplet behaves as an open reactor, in agreement with other studies. ${ }^{35,52}$ Therefore, present observations of products with high yields, exceeding unity values from bulk reagent concentration, occur because iodide is continuously replenished after interacting with $\mathrm{O}_{3}(\mathrm{~g})$.

Effect of Solvent: Solutions in Acetonitrile and Methanol. Solutions of NaI prepared in pure acetonitrile or methanol were aerosolized to compare any solvent dependent changes in the reaction mechanism in water. The experiments provide a better understanding of the interfacial reactivity of $\mathrm{I}^{-}$ with $\mathrm{O}_{3}(\mathrm{~g})$. The unique properties of each solvent represent possible differences existing in the surface coverage of marine aerosols. Sum-frequency generation vibrational spectroscopy measurements showed that the outer layer of the methanol-air interface is covered by methyl groups instead of the $-\mathrm{OH}$ found in water. ${ }^{53}$ The methanol-air interface has the polar $-\mathrm{OH}$ group pointing into the core of the droplets. In contrast, the configuration of acetonitrile in the liquid-air interface is composed of single-disordered molecules with a significant tendency to form antiparallel dipole pairs. ${ }^{54}$ All anions present during the reaction are oriented to minimize the distortion of both interfaces. ${ }^{18}$

No evaluation of the species generated during the ozonolysis of iodide in methanol was reported for the branching ratio $\left[\mathrm{IO}_{3}^{-}\right] /\left[\mathrm{I}_{3}^{-}\right]^{28}$ Therefore, the objective of Supporting Information Figures $\mathrm{S} 1-\mathrm{S} 3$ is to display the identity of the reaction products in acetonitrile and methanol versus water for three different $\left[\mathrm{O}_{3}(\mathrm{~g})\right]$. For example, the key peak at $m / z=143$ for hypoiodite is reported here for the first time in water, methanol, and acetonitrile.

The fact that $\mathrm{O}_{3}(\mathrm{~g})$ reacts with $\mathrm{I}^{-}$in acetonitrile and methanol to form the same products observed in water suggests a common oxidation mechanism. When a $\mathrm{NaI}$ solution in acetonitrile reacts with $2.459 \mathrm{ppmv} \mathrm{O}_{3}(\mathrm{~g})$, the relative ion count for the production of $\mathrm{IO}^{-}, \mathrm{IO}_{2}{ }^{-}$, and $\mathrm{IO}_{3}{ }^{-}$drops 25,14 , and 29 times, respectively, relative to water (Figures S1 and S2 in Supporting Information). Therefore, the anion $\mathrm{IO}^{-}$can undergo direct oxidation even under aprotic conditions. Furthermore, for 2.459 ppmv $\mathrm{O}_{3}(\mathrm{~g})$ reacting with $\mathrm{I}^{-}$in methanol, the three oxyanions are 111, 85, and 220 times less abundant than in water (Figures S1 and S3 in Supporting Information). Remarkably, the production of $\mathrm{H}_{2} \mathrm{O} \cdot \mathrm{IO}^{-}(\mathrm{m} / z=$ 161) and the intermediate $\mathrm{HI}_{2} \mathrm{O}^{-}(m / z=271)$ in methanol and acetonitrile is not observed in the time scale of our measurements. Therefore, we propose that hydrated hypoiodous acid is a key intermediate for the production of iodine oxyanions, while naked $\mathrm{HIO}$ is a main precursor of $\mathrm{I}_{2}$ and $\mathrm{I}_{3}^{-}$.

The different relative abundances for oxyanion products registered in organic solvents also suggests a shorter droplet lifetime together with a more favorable liquid-to-gas transfer for species that do not contain oxygen atoms (Figures S1-S3). The gradual volatility increase accompanying the simultaneous decrease in boiling temperatures $T_{\mathrm{b} \text {,water }}>T_{\mathrm{b} \text {,acetonitrile }}>$ $T_{\mathrm{b} \text {,methanol }}\left(100>82>65{ }^{\circ} \mathrm{C}\right)$ and surface tension $\gamma_{\text {water }}>$ $\gamma_{\text {acetonitrile }}>\gamma_{\text {methanol }}\left(72>29>22 \mathrm{dyn} \mathrm{cm}^{-1}\right),{ }^{55}$ results in a shorter contact time between $\mathrm{O}_{3}, \mathrm{I}^{-}$, and their products in the droplets. ${ }^{56}$ Possibly, the shorter lifetime of the organic droplets favors the reaction of first generation oxidation product $\mathrm{HIO}$ with nearby and more abundant $\mathrm{I}^{-}$to generate $\mathrm{I}_{2}$ and later enhance the intradroplet concentration of $\mathrm{I}_{3}{ }^{-}$. The unfavorable channel of $\mathrm{IO}_{3}^{-}$production presumably requires a longer contact time for the reaction with $\mathrm{O}_{3}$ or the presence of $\mathrm{H}_{2} \mathrm{O}$. $\mathrm{IO}^{-}$.

Enhanced Dissolution of Ozone by Electrolytes. The dissolution of $\mathrm{O}_{3}(\mathrm{~g})$ in microdroplets for increasing [NaI] and $[\mathrm{NaBr}]$ is quantified from the single ion monitoring (SIM) MS at $m / z=48$, background subtracted from the ion count registered in pure water, and finally converted to aqueous solubility by Henry's law (Figure S4, Supporting Information). The Henry's law constant $H_{0}=0.011 \mathrm{M} \mathrm{atm}^{-1}$, ${ }^{47}$ the vapor pressure of water $P_{\mathrm{H}_{2} \mathrm{O}}=0.0312 \mathrm{~atm}^{55}$ at $298 \mathrm{~K}$, and $P_{\mathrm{O}_{3}}=2.459$ ppmv are used in the conversion. The Henry's law constant $H$ remains practically equal to its value in pure water $H_{0}$ in the presence of dilute electrolytes. Supporting Information Figure $\mathrm{S} 4$ also represents the percentage increase of $\mathrm{O}_{3}$ dissolution by aqueous microdroplets containing electrolytes.

Since the Sechenov equation ${ }^{37,58}$ at constant temperature and $\mathrm{pH}$ fails to explain the behavior of $\mathrm{O}_{3}$ observed in Supporting Information Figure S4, a modified eq 1 is introduced for simple dilute electrolytes $([\mathrm{NaX}] \rightarrow 0)$. Equation 1 predicts the solubility increment of the gas in short-lived micrometer size water droplets:

$$
\left[\mathrm{O}_{3}\right]=\left[\mathrm{O}_{3}\right]_{0}+\left[\mathrm{O}_{3}\right]_{100 \mu \mathrm{M}}\left(1-\exp ^{-\left(K_{\mathrm{G}}[\mathrm{NaX}]\right)}\right)
$$

where $\left[\mathrm{O}_{3}\right]_{100 \mu \mathrm{M}}$ indicates the amplitude in Supporting Information Figure $\mathrm{S} 4, \mathrm{~K}_{\mathrm{G}}$ is a constant, and $\left[\mathrm{O}_{3}\right]_{0}$ is the offset from zero. Indeed, the experimental results reflect the uptake of $\mathrm{O}_{3}$ at the air-water interface in $\tau=1 \mu \mathrm{s}$. The best fitting parameters describing Supporting Information Figure S4 with eq 1 for each halide are $\left[\mathrm{O}_{3}\right]_{\mathrm{Br}}-=2.78 \times 10^{-2}+6.16 \times$ $10^{-1}\left(1-\exp ^{-5.43 \times 10^{-2}[\mathrm{NaBr}]}\right)$ and $\left[\mathrm{O}_{3}\right]_{\mathrm{I}-}=2.76 \times 10^{-2}+5.27 \times$ $10^{-1}\left(1-\exp ^{-3.85 \times 10^{-2}[\mathrm{Nal}]}\right)$, both with coefficient of correlation $r^{2} \geq 0.990$.

Present measurements represent a steady state $\left(\mathrm{d}\left[\mathrm{O}_{3}\right] / \mathrm{d} t\right.$ $=0$ ) at the interface because no accumulation occurs over time. The mass transfer of gaseous ozone below $1 \mu \mathrm{M}$ sodium halide is practically constant for both species, and suddenly increases above this concentration indicated by a perpendicular dashed line in Supporting Information Figure S4. Therefore, the mass transfer of $\mathrm{O}_{3}(\mathrm{~g})$ into the aqueous phase is the most important phenomena affecting the experiment in Supporting Information Figure $\mathrm{S} 4$, followed by the reactivity of $\mathrm{O}_{3}$ with $\mathrm{I}^{-}$, because other individual halides remain inert. A simple comparison of the amplitude in Supporting Information Figure S4 shows that $\left[\mathrm{O}_{3}\right]_{100 \mu \mathrm{M}}$ in $\mathrm{I}^{-}$is only a $14 \%$ lower than in $\mathrm{Br}^{-}$. 
The measured $\left[\mathrm{O}_{3}\right]$ depends on time, the liquid film mass transfer coefficient, and the interfacial area of the microdroplets. ${ }^{59}$ The rate of autodecomposition of ozone in the interfacial layer can be neglected in the ultrafast contact time of our measurements. Therefore, the observable $\left[\mathrm{O}_{3}\right]$ cannot be related to the solubility concentration in a bulk solution that is typically less than the equilibrium concentration due to autodecomposition. Instead, the enhanced change in $\left[\mathrm{O}_{3}\right]$, expressed as a percentage, represents the actual solubility concentration in the interfacial region where mass transfer takes place. In other words, since the MS monitors the process occurring on the outer layers of the microdroplets, ${ }^{18}$ the interfacial concentration $\left[\mathrm{O}_{3}\right]_{\text {interface }}$ is assumed equal to the equilibrium concentration $\left[\mathrm{O}_{3}\right]$.

The uptake of ozone by water implies several steps related to properties of the interface, gas- and condensed-phases. The uptake process starts with the diffusion of $\mathrm{O}_{3}(\mathrm{~g})$ molecules toward the water interface, followed by the mass transfer across the interface (accommodation process), diffusion and reaction with iodide in the condensed phase, and desorption of the gasphase reaction products. The surface density of ozone molecules in the interface, $S_{\mathrm{O}_{3}}$ (molecules $\mathrm{cm}^{-2}$ ), can be estimated from the concentration of dissolved ozone $\left[\mathrm{O}_{3}\right]$ (molecules $\mathrm{cm}^{-3}$ ) in the thin slab of thickness $\delta=1 \times 10^{-7} \mathrm{~cm}$ from the equation

$$
S_{\mathrm{O}_{3}}=\delta\left[\mathrm{O}_{3}\right]=v_{\mathrm{O}_{3}} \tau \gamma_{\mathrm{w}}\left[\mathrm{O}_{3}(g)\right] / 4
$$

where $v_{O_{3}}=3.94 \mathrm{~cm} \mathrm{~s}^{-1}$ is the mean thermal velocity of gaseous ozone at $298 \mathrm{~K},\left[\mathrm{O}_{3}(\mathrm{~g})\right]$ is the concentration of ozone molecules striking the liquid microdroplets with a contact time $\tau=1 \times 10^{-6} \mathrm{~s}$, and $\gamma_{\mathrm{w}}$ is the uptake coefficient of ozone in water. Considering the uptake in Supporting Information Figure S4, for dilute $100 \mu \mathrm{M} \mathrm{NaBr}$ aerosolized solution for microdroplets exposed to $P_{\mathrm{O}_{3}}=2.459$ ppmv yields $\gamma_{\mathrm{w}}=4.45 \times$ $10^{-7}$, a low limit that is comparable to the value obtained at interfaces for bromide ${ }^{56}$ or anthracene. ${ }^{60}$

Effect of Surfactant. Many organic compounds present in surface ocean water are surfactant agents also emitted to the atmosphere as part of sea spray aerosol. Therefore, it is important to explore the effect of surfactants on the oxidation of iodide. Figure 4 shows that the nonionic surfactant polysorbate 20 has a minor effect during the ozonolysis of iodide below [polysorbate 20] $=10^{-5} \mathrm{~mol} \mathrm{~L}^{-1}$. The addition of the surfactant below the critical micelle concentration $(\mathrm{CMC})^{61}$ to the $\mathrm{NaI}$ solution exposed to $2.705 \mathrm{ppmv} \mathrm{O}_{3}(\mathrm{~g})$ decreases the total ion count and alters the interface. The surfactant forms micelles at the CMC, ${ }^{61} 8.0 \times 10^{-5} \mathrm{M}$ of polysorbate $20 .{ }^{62}$ For low surfactant concentration the normalized ion count in the presence of surfactant, are close to their values in water as indicated by the proximity of the experimental points to the horizontal dashed line. The highest ion count corresponds always to HIO for the whole [polysorbate 20] interval. At this $\left[\mathrm{O}_{3}(\mathrm{~g})\right]$, the ion $\mathrm{IO}^{-}$covers the majority of the interfacial layer for surfactant and surfactantfree solutions.

The results for low [polysorbate 20] indicate the fast bulk accommodation of $\mathrm{O}_{3}(\mathrm{~g})^{9}$ is still the controlling factor for reaction 1 . Under these conditions, polysorbate 20 behaves as a nonreactive amphiphile, ${ }^{10}$ with a behavior similar to a short chained permeable surfactant such as undissociated nonanoic acid $\left(\mathrm{C}_{9}\right),{ }^{10}$ which minimally affects the uptake coefficient of $\mathrm{O}_{3}\left(\gamma_{\mathrm{w}}=1.1 \times 10^{-2}\right.$ for deliquesced KI particles $) .{ }^{10}$ However, a

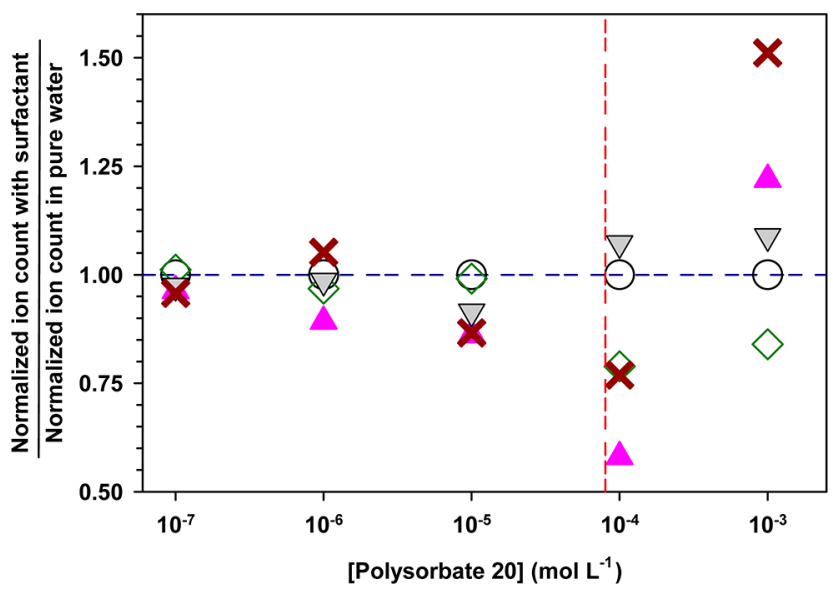

Figure 4. Ratios of normalized ion count in the presence and absence of surfactant for $\left[\mathrm{I}^{-}\right]_{0}=50 \mu \mathrm{M}$ at $\mathrm{pH}=6.2$ and $2.705 \mathrm{ppmv} \mathrm{O}_{3}(\mathrm{~g})$, at variable concentration of polysorbate 20: (pink triangle) $\mathrm{I}^{-}$, (open circle) $\mathrm{IO}^{-}$, (red $\left.\times\right) \mathrm{I}_{3}^{-}$, (green open triangle) $\mathrm{IO}_{2}{ }^{-}$, and (gray inverted triangle) $\mathrm{IO}_{3}^{-}$. The red dashed vertical line indicates the critical micelle concentration, ${ }^{62}$ and the blue dashed horizontal line represents no change in the presence of surfactant relative to pure water microdroplets.

different behavior may occur in the presence of reactive organic species that can compete with $\mathrm{I}^{-}$to react with $\mathrm{O}_{3}(\mathrm{~g})$, such as amphiphilic fulvic acids that can transfer $\mathrm{H}_{\text {interface }}^{+}$through weak carboxylic acids moieties, and enhance the emission of $\mathrm{I}_{2}(\mathrm{~g})$ from submicrometer particles. ${ }^{12,13}$

Significant changes occur above the CMC (vertical red dashed line in Figure 4). For [polysorbate 20] $=10^{-4} \mathrm{M}$, there is an abrupt interfacial depletion of $\mathrm{I}^{-}<\mathrm{I}_{3}{ }^{-}<\mathrm{IO}_{2}{ }^{-}$, and a minor enrichment in the production of $\mathrm{IO}_{3}{ }^{-}$in the reactive surface layers. In the presence of $1 \mathrm{mM}$ surfactant, $\mathrm{I}_{3}{ }^{-}, \mathrm{I}^{-}$, and $\mathrm{IO}_{3}{ }^{-}$ become approximately 50,20, and $7 \%$ more enriched than in water. At high surfactant loading, the ions compete for the surface sites based on their relative concentration in a process strongly influenced by their size, polarizability, and geometry. ${ }^{18}$ The surfactant produces a salting out or salting in of the ions relative to the hydrophobic groups of polysorbate $20 .^{61}$ At 1 $\mathrm{mM}$, the hydrophobic groups of the surfactant are not in contact with the aqueous phase in the micellar form, favoring the salting out of the largest $\mathrm{I}_{3}{ }^{-}$ion. The strong salt out of even low amounts of $\mathrm{I}_{3}{ }^{-}$reflects its ability to highly alter interfacial water structure. ${ }^{61}$ However, the presence of surfactant does not prevent the loss of ozone and the production of $\mathrm{I}_{2}$ and HIO.

Atmospheric Implications. The mechanism investigated here indicates that inorganic processes in sea salt spray could also be an important source of halogens, particularly gaseous $\mathrm{I}_{2}$ and HOI, in the MBL. Both photoactive species HIO and $\mathrm{I}_{2}$ produce iodine atoms in the gas-phase, capable of forming the iodine monoxide radical $\left(\mathrm{IO}^{\bullet}\right)$, and regenerate $\mathrm{I}^{\bullet}$ by different pathways of ozone loss. ${ }^{63}$ This was pointed out using processes at the air-sea interface as a source, ${ }^{24}$ and here we expand the potential sources to sea spray. This process occurs throughout the ocean, and thus impacts the global tropospheric ozone budget. The interaction of $\mathrm{O}_{3}(\mathrm{~g})$ with nano- and micromolar solutions of $\mathrm{I}^{-}$in the presence of $\mathrm{Cl}^{-}, \mathrm{Br}^{-}$, and surfactants generate reactive iodine species even at nighttime. ${ }^{64}$ In sea spray at low $\left[\mathrm{I}^{-}\right]$, considerable $[\mathrm{HIO}]$ can be produced in situ in interfacial reactions that facilitate its transfer to the gas-phase.

One-dimensional models of the $\mathrm{MBL}^{24}$ have been used to estimate the source from the sea for a given set of average 
conditions. However, the actual source will vary geographically. Production of sea spray will be very sensitive to local conditions, particularly surface winds. The production of iodine (Scheme 2) will depend on temperature, humidity, $\mathrm{pH}$, the concentration of halogen species in the liquid phase, and droplet size. Finally, the balance between transport of ozone from the continents to the ocean, and its loss in the MBL is best simulated by global three-dimensional models which include complete gas phase chemistry and long-range transport.

Future modeling efforts should apply first a chemistrydiffusion-evaporation model of the droplet to derive pseudo first order rates for the "net" source processes described in reactions 1 and 5 (Scheme 2 and Table 1). Reaction 1 constitutes a direct loss of ozone on the gas-phase surface, in addition to contributing to iodine production, which also leads to ozone destruction. Scheme 2 also suggests another heterogeneous loss of $\mathrm{O}_{3}$ through (net) reaction 4 (Table 1). We expect that all the above parametrizations will include a dependence on temperature, humidity, $\mathrm{pH}$ and possibly droplet size, resulting from such dependencies of the relevant Henry's law constant, evaporation rates, and aqueous reactions. Such parametrizations exist for some of the chlorine and bromine reactions ${ }^{37}$ that take place in polar stratospheric clouds and which contribute to the formation of the ozone hole.

\section{ASSOCIATED CONTENT}

\section{S Supporting Information}

Detailed experimental section, additional results and discussion, and Figures S1-S4. This information is available free of charge via the Internet at http://pubs.acs.org.

\section{AUTHOR INFORMATION}

\section{Corresponding Author}

*E-mail: marcelo.guzman@uky.edu.

\section{Notes}

The authors declare no competing financial interest.

\section{ACKNOWLEDGMENTS}

We thank research funding from NASA (NNX10AV39A) and NSF CAREER award (CHE-1255290).

\section{REFERENCES}

(1) Forster, P.; Ramaswamy, V.; Artaxo, P.; Berntsen, T.; Betts, R.; Fahey, D. W.; Haywood, J.; Lean, J.; Lowe, D. C.; Myhre, G.; Nganga, J.; Prinn, R.; Raga, G.; Schulz, M.; Van Dorland, R. Changes in atmospheric constituents and in radiative forcing. In Climate Change 2007: The Physical Science Basis. Contribution of Working Group I to the Fourth Assessment Report of the Intergovernmental Panel on Climate Change; Solomon, S., Qin, D., Manning, M., Chen, Z., Marquis, M., Averyt, K. B., Tignor, M., Miller, H. L., Eds.; Cambridge University Press: Cambridge, United Kingdom, 2007.

(2) Denman, K. L.; Brasseur, G.; Chidthaisong, A.; Ciais, P.; Cox, P. M.; Dickinson, R. E.; Hauglustaine, D.; Heinze, C.; Holland, E.; Jacob, D.; Lohmann, U.; Ramachandran, S.; da Silva Dias, P. L.; Wofsy, S. C.; Zhang, X. Couplings between changes in the climate system and biogeochemistry. In Climate Change 2007: The Physical Science Basis. Contribution of Working Group I to the Fourth Assessment Report of the Intergovernmental Panel on Climate Change; Solomon, S., Qin, D., Manning, M., Chen, Z., Marquis, M., Averyt, K. B., Tignor, M., Miller, H. L., Eds.; Cambridge University Press: Cambridge, United Kingdom, 2007.

(3) Murphy, D. M.; Fahey, D. W. An estimate of the flux of stratospheric reactive nitrogen and ozone into the troposphere. $J$. Geophys. Res.: Atmos. 1994, 99 (D3), 5325-5332.
(4) Read, K. A.; Mahajan, A. S.; Carpenter, L. J.; Evans, M. J.; Faria, B. V. E.; Heard, D. E.; Hopkins, J. R.; Lee, J. D.; Moller, S. J.; Lewis, A. C.; Mendes, L.; McQuaid, J. B.; Oetjen, H.; Saiz-Lopez, A.; Pilling, M. J.; Plane, J. M. C. Extensive halogen-mediated ozone destruction over the tropical Atlantic Ocean. Nature 2008, 453 (7199), 1232-1235.

(5) Barrie, L. A.; Bottenheim, J. W.; Schnell, R. C.; Crutzen, P. J.; Rasmussen, R. A. Ozone destruction and photochemical reactions at polar sunrise in the lower Arctic atmosphere. Nature 1988, 334 (6178), 138-141.

(6) Carpenter, L. J.; Hopkins, J. R.; Jones, C. E.; Lewis, A. C.; Parthipan, R.; Wevill, D. J.; Poissant, L.; Pilote, M.; Constant, P. Abiotic source of reactive organic halogens in the sub-Arctic atmosphere? Environ. Sci. Technol. 2005, 39 (22), 8812-8816.

(7) Wren, S. N.; Donaldson, D. J. Glancing-angle Raman spectroscopic probe for reaction kinetics at water surfaces. Phys. Chem. Chem. Phys. 2010, 12 (11), 2648-2654.

(8) Reeser, D. I.; Donaldson, D. J. Influence of water surface properties on the heterogeneous reaction between $\mathrm{O}_{3}(\mathrm{~g})$ and $\mathrm{I}(\mathrm{aq})^{-}$. Atmos. Environ. 2011, 45 (34), 6116-6120.

(9) Rouvière, A. 1.; Sosedova, Y.; Ammann, M. Uptake of ozone to deliquesced $\mathrm{KI}$ and mixed $\mathrm{KI} / \mathrm{NaCl}$ aerosol particles. J. Phys. Chem. A 2010, 114 (26), 7085-7093.

(10) Rouvière, A.; Ammann, M. The effect of fatty acid surfactants on the uptake of ozone to aqueous halogenide particles. Atmos. Chem. Phys. 2010, 10 (23), 11489-11500.

(11) Hayase, S.; Yabushita, A.; Kawasaki, M.; Enami, S.; Hoffmann, M. R.; Colussi, A. n. J. Heterogeneous reaction of gaseous ozone with aqueous iodide in the presence of aqueous organic species. J. Phys. Chem. A 2010, 114 (19), 6016-6021.

(12) Hayase, S.; Yabushita, A.; Kawasaki, M.; Enami, S.; Hoffmann, M. R.; Colussi, A. n. J. Weak acids enhance halogen activation on atmospheric water's surfaces. J. Phys. Chem. A 2011, 115 (19), 49354940.

(13) Hayase, S.; Yabushita, A.; Kawasaki, M. Iodine emission in the presence of humic substances at the water's surface. J. Phys. Chem. A 2012, 116 (24), 5779-5783.

(14) Simpson, W. R.; von Glasow, R.; Riedel, K.; Anderson, P.; Ariya, P.; Bottenheim, J.; Burrows, J.; Carpenter, L. J.; Frieß, U.; Goodsite, M. E.; Heard, D.; Hutterli, M.; Jacobi, H. W.; Kaleschke, L.; Neff, B.; Plane, J.; Platt, U.; Richter, A.; Roscoe, H.; Sander, R.; Shepson, P.; Sodeau, J.; Steffen, A.; Wagner, T.; Wolff, E. Halogens and their role in polar boundary-layer ozone depletion. Atmos. Chem. Phys. 2007, 7 (16), 4375-4418

(15) Huang, R. J.; Seitz, K.; Buxmann, J.; Pöhler, D.; Hornsby, K. E.; Carpenter, L. J.; Platt, U.; Hoffmann, T. In situ measurements of molecular iodine in the marine boundary layer: the link to macroalgae and the implications for $\mathrm{O}_{3}, \mathrm{IO}$, OIO and $\mathrm{NO}_{\mathrm{x}}$. Atmos. Chem. Phys. 2010, 10 (10), 4823-4833.

(16) Huang, R. J.; Thorenz, U. R.; Kundel, M.; Venables, D. S.; Ceburnis, D.; Ho, K. F.; Chen, J.; Vogel, A. L.; Küpper, F. C.; Smyth, P. P. A.; Nitschke, U.; Stengel, D. B.; Berresheim, H.; O’Dowd, C. D.; Hoffmann, T. The seaweeds Fucus vesiculosus and Ascophyllum nodosum are significant contributors to coastal iodine emissions. Atmos. Chem. Phys. 2013, 13 (10), 5255-5264.

(17) von Glasow, R. Atmospheric chemistry: Sun, sea and ozone destruction. Nature 2008, 453 (7199), 1195-1196.

(18) Guzman, M. I.; Athalye, R. R.; Rodriguez, J. M. Concentration effects and ion properties controlling the fractionation of halides during aerosol formation. J. Phys. Chem. A 2012, 116 (22), 54285435.

(19) Garland, J. A.; Curtis, H. Emission of iodine from the sea surface in the presence of ozone. J. Geophys. Res.-Oceans 1981, 86 (C4), $3183-3186$

(20) Saunders, R. W.; Kumar, R.; MacDonald, S. M.; Plane, J. M. C. Insights into the photochemical transformation of iodine in aqueous systems: Humic acid photosensitized reduction of iodate. Environ. Sci. Technol. 2012, 46 (21), 11854-11861.

(21) Liao, J.; Sihler, H.; Huey, L. G.; Neuman, J. A.; Tanner, D. J.; Friess, U.; Platt, U.; Flocke, F. M.; Orlando, J. J.; Shepson, P. B.; Beine, 
H. J.; Weinheimer, A. J.; Sjostedt, S. J.; Nowak, J. B.; Knapp, D. J.; Staebler, R. M.; Zheng, W.; Sander, R.; Hall, S. R.; Ullmann, K. A comparison of Arctic $\mathrm{BrO}$ measurements by chemical ionization mass spectrometry and long path-differential optical absorption spectroscopy. J. Geophys. Res.: Atmos. 2011, 116, No. D00R02.

(22) Hunt, S. W.; Roeselová, M.; Wang, W.; Wingen, L. M.; Knipping, E. M.; Tobias, D. J.; Dabdub, D.; Finlayson-Pitts, B. J. Formation of molecular bromine from the reaction of ozone with deliquesced $\mathrm{NaBr}$ aerosol: Evidence for interface chemistry. J. Phys. Chem. A 2004, 108 (52), 11559-11572.

(23) Sakamoto, Y.; Yabushita, A.; Kawasaki, M.; Enami, S. Direct emission of $\mathrm{I}_{2}$ molecule and $\mathrm{IO}$ radical from the heterogeneous reactions of gaseous ozone with aqueous potassium iodide solution. $J$. Phys. Chem. A 2009, 113 (27), 7707-7713.

(24) Carpenter, L. J.; MacDonald, S. M.; Shaw, M. D.; Kumar, R.; Saunders, R. W.; Parthipan, R.; Wilson, J.; Plane, J. M. C. Atmospheric iodine levels influenced by sea surface emissions of inorganic iodine. Nat. Geosci. 2013, 6 (2), 108-11.

(25) Reiter, R. Charges on particles of different size from bubbles of mediterranea-sea surf and from waterfalls. J. Geophys. Res.: Atmos. 1994, 99 (D5), 10807-10812.

(26) Bhattacharyya, I.; Maze, J. T.; Ewing, G. E.; Jarrold, M. F. Charge separation from the bursting of bubbles on water. J. Phys. Chem. A 2011, 115 (23), 5723-5728.

(27) Blanchard, D. C. Electrically charged drops from bubbles in sea water and their meteorological significance. J. Meteorol. 1958, 15 (4), 383-396.

(28) Cheng, J.; Hoffmann, M. R.; Colussi, A. J. Anion fractionation and reactivity at air/water:methanol interfaces. Implications for the origin of Hofmeister effects. J. Phys. Chem. B 2008, 112 (24), 71577161

(29) Cheng, J.; Vecitis, C. D.; Hoffmann, M. R.; Colussi, A. J. Experimental anion affinities for the air/water interface. J. Phys. Chem. B 2006, 110 (51), 25598-25602.

(30) Platt, U.; Honninger, G. The role of halogen species in the troposphere. Chemosphere 2003, 52 (2), 325-338.

(31) O’Dowd, C. D.; Jimenez, J. L.; Bahreini, R.; Flagan, R. C.; Seinfeld, J. H.; Hameri, K.; Pirjola, L.; Kulmala, M.; Jennings, S. G.; Hoffmann, T. Marine aerosol formation from biogenic iodine emissions. Nature 2002, 417 (6889), 632-636.

(32) Thomas, J. L.; Jimenez-Aranda, A.; Finlayson-Pitts, B. J.; Dabdub, D. Gas-phase molecular halogen formation from $\mathrm{NaCl}$ and $\mathrm{NaBr}$ aerosols: When are interface reactions important? J. Phys. Chem. A 2006, 110 (5), 1859-1867.

(33) McMurdo, C. J.; Ellis, D. A.; Webster, E.; Butler, J.; Christensen, R. D.; Reid, L. K. Aerosol enrichment of the surfactant PFO and mediation of the water-air transport of gaseous PFOA. Environ. Sci. Technol. 2008, 42 (11), 3969-3974.

(34) Finlayson-Pitts, B. J. Halogens in the troposphere. Anal. Chem. 2009, 82 (3), 770-776.

(35) Enami, S.; Vecitis, C. D.; Cheng, J.; Hoffmann, M. R.; Colussi, A. J. Global inorganic source of atmospheric bromine. J. Phys. Chem. A 2007, 111 (36), 8749-8752.

(36) Enami, S.; Vecitis, C. D.; Cheng, J.; Hoffmann, M. R.; Colussi, A. J. Mass spectrometry of interfacial layers during fast aqueous aerosol/ozone gas reactions of atmospheric interest. Chem. Phys. Lett. 2008, 455 (4-6), 316-320.

(37) Sander, S. P.; Abbatt, J.; Barker, J. R.; Burkholder, J. B.; Friedl, R. R.; Golden, D. M.; Huie, R. E.; Kolb, C. E.; Kurylo, M. J.; Moortgat, G. K.; Orkin, V. L.; Wine, P. H. Chemical Kinetics and Photochemical Data for Use in Atmospheric Studies: Evaluation Number 17. Jet Propulsion Laboratory, California Institute of Technology: Pasadena, CA, 2011; http://jpldataeval.jpl.nasa.gov.

(38) Bichsel, Y.; von Gunten, U. Oxidation of iodide and hypoiodous acid in the disinfection of natural waters. Environ. Sci. Technol. 1999, 33 (22), 4040-4045.

(39) Eigen, M.; Kustin, K. The kinetics of halogen hydrolysis. J. Am. Chem. Soc. 1962, 84 (8), 1355-1361.
(40) Hao, C.; March, R. E.; Croley, T. R.; Smith, J. C.; Rafferty, S. P. Electrospray ionization tandem mass spectrometric study of salt cluster ions. Part 1: Investigations of alkali metal chloride and sodium salt cluster ions. J. Mass. Spec. 2001, 36 (1), 79-96.

(41) Troy, R. C.; Kelley, M. D.; Nagy, J. C.; Margerum, D. W. Nonmetal redox kinetics: iodine monobromide reaction with iodide ion and the hydrolysis of IBr. Inorg. Chem. 1991, 30 (25), 4838-4845.

(42) Von Sonntag, C.; Von Gunten, U. Chemistry of Ozone in Water and Wastewater Treatment: From Basic Principles to Applications; IWA Publishing: London, 2012; p 302.

(43) Palmer, D. A.; Ramette, R. W.; Mesmer, R. E. The hydrolysis of iodine: Equilibria at high temperatures. J. Nucl. Mater. 1985, 130 (0), 280-286.

(44) Bichsel, Y.; von Gunten, U. Hypoiodous acid: Kinetics of the buffer-catalyzed disproportionation. Water Res. 2000, 34 (12), 31973203.

(45) Lin, C.-C. Volatility of iodine in dilute aqueous solutions. J. Inorg. Nucl. Chem. 1981, 43 (12), 3229-3238.

(46) Magi, L.; Schweitzer, F.; Pallares, C.; Cherif, S.; Mirabel, P.; George, C. Investigation of the uptake rate of ozone and methyl hydroperoxide by water surfaces. J. Phys. Chem. A 1997, 101 (27), 4943-4949.

(47) Standard Reference Database 69. The NIST Chemistry WebBook; Mallard, W. G., Linstrom, P. J., Eds.; National Institute of Standards and Technology: Gaithersburg, MD, 2000; http://webbook.nist.gov, Vol. 2012.

(48) Enami, S.; Hoffmann, M. R.; Colussi, A. J. Proton availability at the air/water interface. J. Phys. Chem. Lett. 2010, 1 (10), 1599-1604.

(49) Petersen, P. B.; Saykally, R. J. Probing the interfacial structure of aqueous electrolytes with femtosecond second harmonic generation spectroscopy. J. Phys. Chem. B 2006, 110 (29), 14060-14073.

(50) van Elk, E. P. Gas-liquid reactions-Influence of bulk and mass transfer on process performance. Ph.D. Thesis, University of Twente, Enschede, 2001.

(51) Benson, S. W. The Foundations of Chemical Kinetics; McGrawHill: New York, 1960; p 736.

(52) Enami, S.; Vecitis, C. D.; Cheng, J.; Hoffmann, M. R.; Colussi, A. J. Electrospray mass spectrometric detection of products and shortlived intermediates in aqueous aerosol microdroplets exposed to a reactive gas. J. Phys. Chem. A 2007, 111 (50), 13032-13037.

(53) Liu, W.-T.; Zhang, L.; Shen, Y. R. Interfacial structures of methanol:water mixtures at a hydrophobic interface probed by sumfrequency vibrational spectroscopy. J. Chem. Phys. 2006, 125 (14), 144711-6.

(54) Ding, F.; Hu, Z.; Zhong, Q.; Manfred, K.; Gattass, R. R.; Brindza, M. R.; Fourkas, J. T.; Walker, R. A.; Weeks, J. D. Interfacial organization of acetonitrile: Simulation and experiment. J. Phys. Chem. C 2010, 114 (41), 17651-17659.

(55) CRC Handbook of Chemistry and Physics, 93rd ed.; CRC Press/ Taylor and Francis: Boca Raton, FL, 2013; p 2664.

(56) Oldridge, N. W.; Abbatt, J. P. D. Formation of gas-phase bromine from interaction of ozone with frozen and liquid $\mathrm{NaCl} / \mathrm{NaBr}$ solutions: Quantitative separation of surficial chemistry from bulkphase reaction. J. Phys. Chem. A 2011, 115 (12), 2590-2598.

(57) Rhim, J. A. Equilibrium concentration and overall Henry's law constant of the dissolved ozone. Env. Eng. Res. 2004, 9 (2), 88-95.

(58) Rischbieter, E.; Stein, H.; Schumpe, A. Ozone solubilities in water and aqueous salt solutions. J. Chem. Eng. Data 2000, 45 (2), 338-340.

(59) Roth, J. A.; Sullivan, D. E. Solubility of ozone in water. Ind. Eng. Chem. Fund. 1981, 20 (2), 137-140.

(60) Mmereki, B. T.; Donaldson, D. J. Direct observation of the kinetics of an atmospherically important reaction at the air-aqueous interface. J. Phys. Chem. A 2003, 107 (50), 11038-11042.

(61) Rosen, M. J. Surfactants and Interfacial Phenomena, 3rd ed.; Wiley: Hoboken, NJ, 2004; p 444.

(62) Kim, C.; Hsieh, Y.-L. Wetting and absorbency of nonionic surfactant solutions on cotton fabrics. Colloids Surf., A 2001, 187-188 (0), 385-397. 
(63) Saiz-Lopez, A.; Plane, J. M. C.; Baker, A. R.; Carpenter, L. J.; von Glasow, R.; Gómez Martín, J. C.; McFiggans, G.; Saunders, R. W. Atmospheric chemistry of iodine. Chem. Rev. 2011, 112 (3), 17731804.

(64) Saiz-Lopez, A.; von Glasow, R. Reactive halogen chemistry in the troposphere. Chem. Soc. Rev. 2012, 41 (19), 6448-6472. 